\title{
Difficulties of technogenic formations roasting products processing into the portland cement clinker in the presence of a significant amount of $\mathrm{SO}_{3}$
}

\author{
Oleg Sheshukov ${ }^{1,2, *}$ and Egiazaryan Denis ${ }^{1,2}$ \\ ${ }^{1}$ Federal State Budgetary Institution of Science Institute of Metallurgy of the Ural Branch of the \\ Russian Academy of Sciences, 620016, Ekaterinburg, Amundsen st., 10, Russia \\ ${ }^{2}$ Federal State Autonomous Educational Institution of Higher Education «Ural Federal University \\ named after the first President of Russia B.N.Yeltsin», 620002, Ekaterinburg, Mira st., 19, Russia
}

\begin{abstract}
Synthesis of the portland cement clinker in the presence of a significant amount of $\mathrm{SO}_{3}$ is difficult due to the tricalcium silicate formation suppression. Since some technogenic formations contain a significant amount of $\mathrm{SO}_{3}$ it is hard to obtain the portland cement clinker from it. The analysis of the $\mathrm{SO}_{3}$ influence on the clinker-formation thermodynamic process allowed to reveal a number of regularities of their occurrence and to propose a method for the raw mix composition calculating and its preparation to ensure a stable portland cement clinker synthesis.
\end{abstract}

Some technogenic formations, for example, sludge from the synthetic fibers production, contain zinc in sulphide form. The feature of the such sludge phase composition is the iron oxides lack in them and the gypsum dihydrate presence. A significant amount of gypsumanhydrite remains in the roasting products after zinc extraction from such sludge. Table 1 shows the phase composition of the sludge roasting products obtained at the temperature of $1100{ }^{\circ} \mathrm{C}$.

To ensure integrated waste-free processing of synthetic fibers production, it is advisable to convert the roasted products after complete extraction of zinc sulfide into portland cement clinker, but the gypsum-anhydrite presence makes it difficult to implement this sludge complex processing direction.

It is well known from the practice of portland cement production that it is difficult to obtain high-quality portland cement clinker from a raw material mixture with a significant amount of gypsum-anhydrite, which is a source of $\mathrm{SO}_{3}$. According to $[1,2]$, with an increase in the $\mathrm{SO}_{3}$ in the raw mixture, the amount of dicalcium silicate $\left(\mathrm{C}_{2} \mathrm{~S}\right)$ increases, tricalcium silicate $\left(\mathrm{C}_{3} \mathrm{~S}\right)$ decreases, and with an equal total content of these phases in the clinker, their $\mathrm{C}_{3} \mathrm{~S} / \mathrm{C}_{2} \mathrm{~S}$ ratio decreases. Since $\mathrm{C}_{3} \mathrm{~S}$ is the most active and refractory component, decrease in its content leads to a decrease in refractoriness and activity of clinker. It was found [3] that with an increase in the content of $\mathrm{SO}_{3}$ in portland cement

* Corresponding author: silast@mail.ru 
clinker, also the tricalcium aluminate $\left(\mathrm{C}_{3} \mathrm{~A}\right)$ content decreases. According to the authors, the reason for the $\mathrm{C}_{3} \mathrm{~A}$ content decrease in high-sulfate clinker is the silicon isomorphic replacement in silicate phases with aluminum. The reasons for the $\mathrm{C}_{3} \mathrm{~S}$ content decrease in portland cement clinker with an $\mathrm{SO}_{3}$ content increase in it was not found in literary sources.

Table 1. The phase composition of the sludge roasting products at $1100^{\circ} \mathrm{C}$.

\begin{tabular}{|l|c|c|}
\hline \multicolumn{1}{|c|}{ Phase name } & Chemical formula & Content, mass. $\%$ \\
\hline Helenite & $2 \mathrm{CaO} \cdot \mathrm{SiO} 2 \cdot \mathrm{Al}^{2} \mathrm{O}_{3}$ & 23,50 \\
\hline Zinc sulfide & $\mathrm{ZnS}$ & 15,3 \\
\hline Mayenite & $12 \mathrm{CaO} \cdot 7 \mathrm{Al}_{2} \mathrm{O}_{3}$ & 6,75 \\
\hline Zinc Oxide (Zincite) & $\mathrm{ZnO}$ & 9,27 \\
\hline Larnit & $2 \mathrm{CaO} \cdot \mathrm{SiO}_{2}$ & 22,07 \\
\hline Gypsum anhydrite & $\mathrm{CaSO} 4$ & 9,11 \\
\hline Zinc Sulfide Oxide (Wurtzite) & $\mathrm{Zn}\left(\mathrm{S}_{0,98} \mathrm{O}_{0,12}\right)$ & 14,0 \\
\hline
\end{tabular}

To identify $\mathrm{C}_{3} \mathrm{~A}$ formation inhibition reasons in high-sulfate clinker, raw mixtures were roasted, designed to produce typical portland cement clinker with modular characteristics of $\mathrm{KN}=0.92, \mathrm{n}=2.3$ and $\mathrm{p}=1.69$. For the portland cement clinker preparation, the raw mix from limestone, clay, quartz sand and natural gypsum was used. During the preparation, the gypsum introduction into the mixture was calculated with following ratio: raw mix/gypsum $-95 / 5 \%$. It was made to achieve more than 2 mass. $\% \mathrm{SO}_{3}$ in the mixture. The mixture was homogenized in a laboratory mill by co-grinding for 30 minutes. The homogeneous mixture was moistened and pressed at the pressure of $50 \mathrm{MPa}$. Samples were roasted at temperatures from 1100 to $1300^{\circ} \mathrm{C}$. The phase analysis data of roasted products are shown in Fig. 1. Free lime contents in the roasted products are presented in table 2.

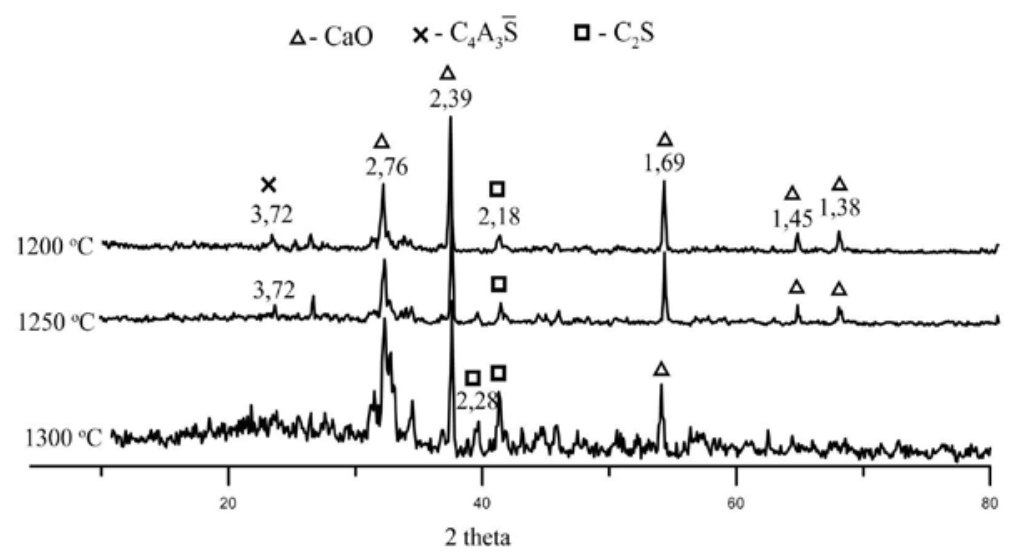

Fig. 1. The phase analysis data of roasted products.

Table 1. Free lime contents in the roasted products

\begin{tabular}{|c|c|c|c|}
\hline $\mathrm{T},{ }^{\circ} \mathrm{C}$ & 1100 & 1200 & 1300 \\
\hline $\mathrm{CaO}$, mass. $\%$ & 14,0 & 13,84 & 11,6 \\
\hline
\end{tabular}

Figure 1 and Table 2 indicate that the introduction of 5 mass.\% gypsum into the raw mix suppresses the $\mathrm{C}_{3} \mathrm{~S}$ formation during roasting. Instead of $\mathrm{C}_{3} \mathrm{~S}$, a significant amount of free lime are remain in the clinker. When similar clinker is heated to the temperature of $1350{ }^{\circ} \mathrm{C}$, it is completely melted. In the melt, that heated up to $1600{ }^{\circ} \mathrm{C}, \mathrm{C}_{3} \mathrm{~S}$ could be 
formed during overheating over melting point, but about $6.2 \%$ of free lime will be present in the melt.

It is likely that the well-crystallized free $\mathrm{CaO}$ formation is responsible for the $\mathrm{C}_{3} \mathrm{~S}$ formation suppression in clinker in the presence of $\mathrm{SO}_{3}$. This phase does not soluble in the melt, so it cannot contribute to the conversion of $\mathrm{C}_{2} \mathrm{~S}$ to $\mathrm{C}_{3} \mathrm{~S}$. The absence of $\mathrm{C}_{3} \mathrm{~S}$ in clinker reduces its refractoriness and promotes the melt appearance at temperatures below the portland cement clinker synthesis temperature.

The formation of a free lime significant amount in clinker during the gypsum decomposition is unlikely. Since, a stoichiometric ratio of $\mathrm{CaO}$ and $\mathrm{SO}_{3}$ in gypsumanhydrite, respectively, 41.19 and 58.81 mass.\%, just 2.06 mass.\% free $\mathrm{CaO}$ may form from decomposition. But at the $1300{ }^{\circ} \mathrm{C}$ more than 11 mass. $\%$ free $\mathrm{CaO}$ was formed during laboratory experiments.

To clarify reasons for the free $\mathrm{CaO}$ significant amount appearance in a high-sulfate clinker, the thermodynamic analysis of $\mathrm{C}_{3} \mathrm{~A}$ and $4 \mathrm{CaO} \cdot \mathrm{Al}_{2} \mathrm{O}_{3} \cdot \mathrm{Fe}_{2} \mathrm{O}_{3}\left(\mathrm{C}_{4} \mathrm{AF}\right)$ formation reactions was carried out according to [4] and the $4 \mathrm{CaO} \cdot 3 \mathrm{Al}_{2} \mathrm{O}_{3}\left(\mathrm{C}_{4} \mathrm{~A}_{3}\right)$ formation according to [5] was carried out. Results given in the table 3.

Table 2. Gibbs energy changes for $\mathrm{C}_{3} \mathrm{~A}$ and $\mathrm{C}_{4} \mathrm{AF}$ formation with temperature rising [4,5].

\begin{tabular}{|c|c|c|c|c|c|c|}
\hline \multirow[t]{2}{*}{ № } & \multirow[t]{2}{*}{ Reaction } & \multicolumn{5}{|c|}{$\Delta \mathrm{G}^{\mathrm{o}}, \mathrm{KJ} / \mathrm{moll}$, accordint to $\mathrm{T}, \mathrm{K}$} \\
\hline & & 298 & 1023 & 1200 & 1400 & 1500 \\
\hline 1 & $3 \mathrm{CaO}+\mathrm{Al}_{2} \mathrm{O}_{3}=3 \mathrm{CaO} \cdot \mathrm{Al}_{2} \mathrm{O}_{3}$ & $-17,0$ & $-41,8$ & $-47,0$ & $-52,9$ & $-55,7$ \\
\hline 2 & $\begin{array}{l}4 \mathrm{CaO}+\mathrm{Al}_{2} \mathrm{O}_{3}+\mathrm{Fe}_{2} \mathrm{O}_{3}= \\
4 \mathrm{CaO} \cdot \mathrm{Al}_{2} \mathrm{O}_{3} \cdot \mathrm{Fe}_{2} \mathrm{O}_{3}\end{array}$ & $-49,3$ & $-64,9$ & $-64,1$ & $-60,83$ & $-58,1$ \\
\hline 3 & $\begin{array}{l}3 \mathrm{CaO}+3 \mathrm{Al}_{2} \mathrm{O}_{3}+\mathrm{CaSO}_{4}= \\
3 \mathrm{CaO} \cdot 3 \mathrm{Al}_{2} \mathrm{O}_{3} \cdot \mathrm{CaSO}_{4}\end{array}$ & $-99,1$ & $-445,1$ & $-583,6$ & $-758,9$ & $-853,5$ \\
\hline 4 & $\mathrm{CaO} \cdot \mathrm{Al}_{2} \mathrm{O}_{3}+2 \mathrm{CaO}=3 \mathrm{CaO} \cdot \mathrm{Al}_{2} \mathrm{O}_{3}$ & $+33,7$ & $+32,3$ & $+31,7$ & $+33,26$ & $+34,4$ \\
\hline 5 & $\begin{array}{l}\mathrm{CaO} \cdot \mathrm{Al}_{2} \mathrm{O}_{3}+\mathrm{CaO}+2 \mathrm{CaO} \cdot \mathrm{Fe}_{2} \mathrm{O}_{3}= \\
4 \mathrm{CaO} \cdot \mathrm{Al}_{2} \mathrm{O}_{3} \cdot \mathrm{Fe}_{2} \mathrm{O}_{3}\end{array}$ & $+10,4$ & $+39,7$ & $+49,0$ & $+60,3$ & $+66,2$ \\
\hline 6 & $\begin{array}{l}\mathrm{CaO} \cdot \mathrm{Al}_{2} \mathrm{O}_{3}+2 \mathrm{CaO}+\mathrm{CaO} \cdot \mathrm{Fe}_{2} \mathrm{O}_{3}= \\
4 \mathrm{CaO} \cdot \mathrm{Al}_{2} \mathrm{O}_{3} \cdot \mathrm{Fe}_{2} \mathrm{O}_{3}\end{array}$ & $+42,45$ & $+72,1$ & $+79,77$ & +79.8 & $+83,7$ \\
\hline
\end{tabular}

According to the given data, in the absence of $\mathrm{SO}_{3}$ in clinker, the $\mathrm{C}_{3} \mathrm{~A}$ and $\mathrm{C}_{4} \mathrm{AF}$ synthesis is thermodynamically possible from simple minerals $\left(\mathrm{CaO}, \mathrm{Al}_{2} \mathrm{O}_{3}\right.$ and $\left.\mathrm{Fe}_{2} \mathrm{O}_{3}\right)$ (reactions 1-2). In the case of the $\mathrm{SO}_{3}$ presence in clinker, the reaction 3 (formation of calcium sulfoaluminate $-\mathrm{C}_{3} \mathrm{~A}_{3} \mathrm{CS}$ ) is thermodynamically preferable, since the Gibbs energy chaqge of this reaction over the entire temperature range is more negative than that of reactions 1 and 2 .

There are different opinions about the mechanism of $\mathrm{C}_{3} \mathrm{~A}_{3} \mathrm{CS}$ formation in clinker during heat. According to [5], the $\mathrm{C}_{3} \mathrm{~A}_{3} \mathrm{CS}$ synthesis, due to an lime excess at the time of its formation, begins with the formation of mayenite (12CaO $7 \mathrm{Al} 2 \mathrm{O} 3-\mathrm{C}_{12} \mathrm{~A}_{7}$ ) according to the scheme $\mathrm{C}_{12} \mathrm{~A}_{7} \rightarrow \mathrm{CA} \rightarrow \mathrm{C}_{3} \mathrm{~A}_{3} \mathrm{CS}$. According to [6], in the pressed raw mixture, due to its higher reactivity, the $\mathrm{C}_{3} \mathrm{~A}_{3} \mathrm{CS}$ synthesis proceeds according to the scheme $\mathrm{CA}_{2} \rightarrow \mathrm{CA} \rightarrow$ $\mathrm{C}_{2} \mathrm{~A}_{2} \rightarrow \mathrm{C}_{3} \mathrm{~A}_{3} \rightarrow \mathrm{C}_{3} \mathrm{~A}_{3} \mathrm{CS}$ with the formation of calcium monoaluminate (CA) at temperatures of about $700{ }^{\circ} \mathrm{C}$ and its presence throughout the entire roasting temperature range up to $1300{ }^{\circ} \mathrm{C}$. The $\mathrm{C}_{3} \mathrm{~A}$ and $\mathrm{C}_{4} \mathrm{AF}$ formation is thermodynamically impossible in the CA presence (reactions $4,5,6$ ).

Consequently, if the raw mix is calculated according to the usual scheme for the $\mathrm{C} 3 \mathrm{~A}$ and $\mathrm{C} 4 \mathrm{AF}$ formation in high-sulfate clinker, but in fact, low-base aluminates and calcium ferrites form in high-sulfate clinker, then reactions 7 and 8 occurs instead of reactions 1 and 2 and lime remains unbound to minerals and free: 


$$
\begin{gathered}
3 \mathrm{CaO}+\mathrm{Al}_{2} \mathrm{O}_{3} \rightarrow \mathrm{CaO} \cdot \mathrm{Al}_{2} \mathrm{O}_{3}+2 \mathrm{CaO}, \\
4 \mathrm{CaO}+\mathrm{Al}_{2} \mathrm{O}_{3}+\mathrm{Fe}_{2} \mathrm{O}_{3} \rightarrow \mathrm{CaO} \cdot \mathrm{Al}_{2} \mathrm{O}_{3}+\mathrm{CaO} \cdot \mathrm{Fe}_{2} \mathrm{O}_{3}+2 \mathrm{CaO} .
\end{gathered}
$$

Free lime accumulates in the clinker from the temperature of calcium carbonate decomposition to the appearance of the liquid phase due to the difference in lime content in the $\mathrm{C}_{3} \mathrm{~A}$, that used in the calculation, and the $\mathrm{CA}$, that actually formed. In total, from the gypsum decomposition and the lime content difference in calcium aluminates, in clinker free lime can remains in an amount of about $5 \%$ in temperature range from calcium carbonate decomposition up to the liquid phase appearance. This amount is sufficient to suppress the $\mathrm{C}_{3} \mathrm{~S}$ formation at the moment of the appearance of liquid phases.

Since in the presence of $\mathrm{SO}_{3}$ only $\mathrm{C}_{2} \mathrm{~S}$ formed in the clinker and $\mathrm{C}_{3} \mathrm{~S}$ is absent, due to the lime content difference in these minerals, the total free lime content reaches 11 mass.\% at synthesis completion temperatures. With an increase in the temperature of the melt up to $1600{ }^{\circ} \mathrm{C}, \mathrm{C}_{3} \mathrm{~S}$ is formed in an insignificant amount, but free $\mathrm{CaO}$ does not dissolve and remains in an amount of about 6 mass.\%.

Taking into account the high-sulfate raw material mixtures test results, a method was developed for calculating the raw mixture composition containing gypsum-anhydrite, which allows $\mathrm{C}_{3} \mathrm{~S}$ significant amount forming in portland cement clinker. This technique was used in calculating the raw material mixture composition based on sludge from the production of synthetic fibers to form portland cement clinker typical phases in it. The data of roasted products phase analysis are presented in fig. 2

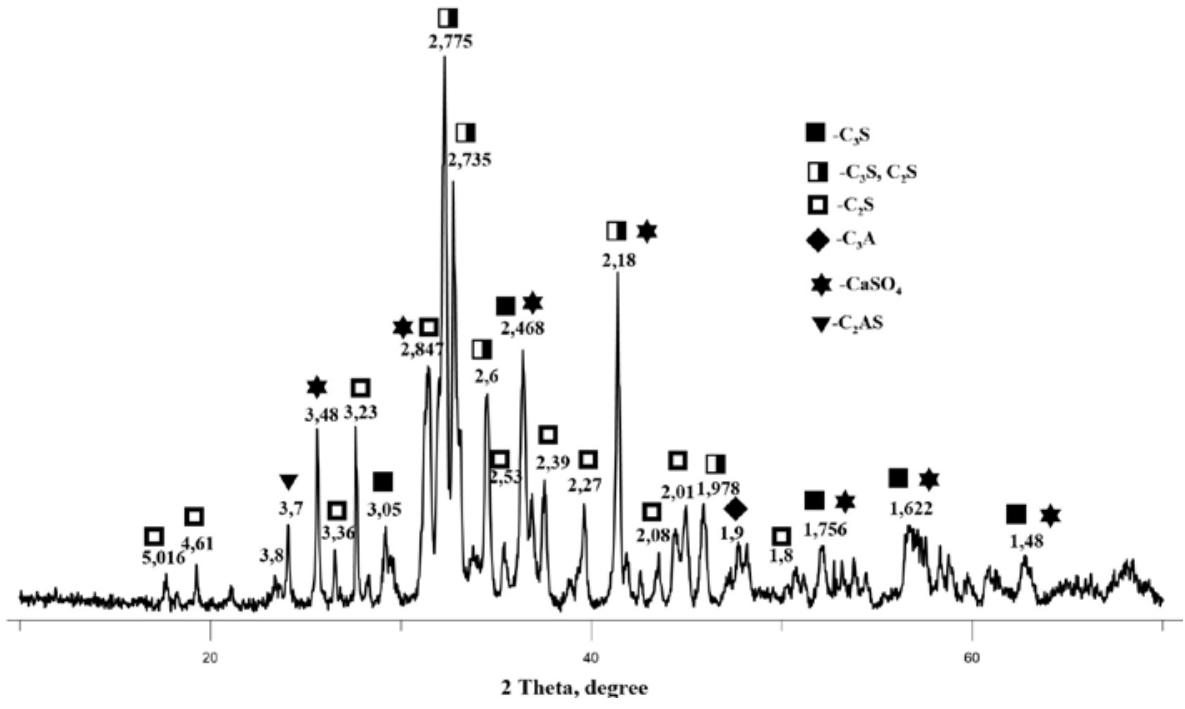

Fig. 2. Phase composition of roasted products.

The phase analysis data show that it is possible to form typical phases of Portland cement clinker in roasted products. There are also gypsum anhydrite remains. Checking the obtained clinker setting time showed that it has normal setting times that meet the regulatory documents requirements.

The reported study was funded by RFBR according to the research project № 18-29-24064\18. 


\section{References}

1. J.I. Bhatty, Role of Minor Elements in Cement Manufacture and Use (Portland Cement Association, Skokie, Illinois, 1995)

2. H. Sayed, R. Ltief, T. Rizk, Influence of the clinker $\mathrm{SO}_{3}$ on the cement characteristics, Cement And Concrete Research 41, pp. 913-919 (2011).

3. H. Sayed, R. Ltief, T. Rizk, Calculation of the $C_{3}$ A Percentage in High Sulfur Clinker, International Journal of Analytical Chemistry, Vol. 2010, 5 pages (2010) Article ID 102146

4. V.I. Babushkin, G.M. Matveev, O.M. Mchedlov-Petrosyan, Thermodynamics of silicates (Moscow, Stroiizdat, 1986)

5. T.V. Kuznetsova, Aluminate and sulfoaluminate cements (Moscow, Stroiizdat, 1986)

6. M.A. Mikheenkov Influence of raw mix pressing on the reduction of energy consumption in the production of cement, ALITinform., № 2., p. 50-57 (2011) 